\title{
Effects of the lateral growth rate on wood quality of Gmelina arborea from 3.5-, 7- and 12-year-old plantations
}

\author{
Miho KoJima $^{1}$, Hiroyuki Yamamoto ${ }^{1 *}$, S. Nugroho Marsoem ${ }^{2}$, Takashi OKUYAmA ${ }^{1}$, \\ Masato YoshidA $^{1}$, Takahisa NAKAI ${ }^{3}$, Saori YAMASHITA ${ }^{1}$, Koichiro SAEGUSA ${ }^{1}$, Kenji MatsunE ${ }^{4}$, \\ Kentaro NAKAMURA ${ }^{4}$, Yoshihiko INOUE ${ }^{4}$, Takeshi ARIZONO ${ }^{5}$, \\ ${ }^{1}$ Graduate School of Bio-agricultural Sciences, Nagoya University, Furo-cho, Chikusa, 464-8601 Nagoya, Japan \\ ${ }^{2}$ Faculty of Forestry, Gadjah Mada University JI. Agro No.1, Bulaksumur, Yogyakarta 55281, Republic of Indonesia \\ ${ }^{3}$ Faculty of Science and Engineering, Shimane University, 1060 Nishikawatsu-cho, Matsue, 690-8504 Shimane, Japan \\ ${ }^{4}$ Sumitomo Forestry Co., LTD N. 3-2 Midorigahara Tsukuba-shi, 300-2646 Ibaraki, Japan \\ ${ }^{5}$ Faculty of Technology, Borneo University, JI. Amal Lama No.01 Tarakan, Kalimantan Timur 77123, Republic of Indonesia
}

(Received 16 May 2008; accepted 23 January 2009)

Keywords:

Gmelina arborea /

lateral growth rate /

tropical rain-forest /

fast-growing species /

xylem quality

\begin{abstract}
- Awareness of the shortage of fossil resources leads to an increasing demand for woody biomass. We investigated the feasibility of using fast-growing Gmelina arborea wood for material production. Gmelina arborea wood samples were collected from trees of varying cambium ages in Indonesia, from 3.5-, 7- and 12-year-old plantations.

- The lateral growth rate and the cambium age did not significantly affect the longitudinal released strain of the growth stress, xylem density, or microfibril angle at the outermost surface of the secondary xylem at any sampling site. However, fiber length in the 3.5-year-old plantation tended to be shorter in smaller diameter trees, whereas in larger diameter trees it was almost the same as that in trees from the 7- and 12-year-old plantations. This suggests that smaller diameter trees in the 3.5year-old plantation had not yet produced mature wood.

- Xylem qualities had already reached values appropriate for harvesting, except in the smaller diameter trees from the 3.5-year-old plantation. This indicates that the larger diameter trees had already matured, regardless of their cambium age. These results suggest that the next step is to develop silvicultural treatments to increase the lateral growth rate during the early growing stage, in order to produce as much mature wood as possible, as quickly as possible.
\end{abstract}

Résumé - Effet du taux radial de croissance sur la qualité du bois de Gmelina arborea provenant de plantations de $3,5,7$ et 12 ans.

- La prise de conscience de la raréfaction des ressources fossiles conduit à une demande croissante de biomasse ligneuse. Dans ce contexte nous avons examiné la faisabilité d'utiliser une essence à croissance rapide Gmelina arborea pour la production de bois matériau.Nous avons collecté en Indonésie des échantillons de bois dans des arbres provenant de plantations de 3,5, 7 et 12 ans.

- Pour tous les sites, le taux de croissance radiale et l'âge cambial n'affectent pas les déformations résiduelles longitudinales des contraintes de croissance, la densité du xylème ou l'angle des microfibrilles de la périphérie du xylème secondaire. Cependant pour les petits arbres de la plantation de 3,5 ans, les fibres sont plus courtes tandis que pour les gros arbres les fibres ont une longueur comparable à celle des arbres des plantations de 7 et 12 ans. Cela suggère que les petits arbres de la plantation de 3,5 ans ne produisent pas encore du bois mature.

- Les qualités du xylème ont facilement atteint des valeurs justifiant l'exploitation exception faite des petits arbres de la plantation de 3,5 ans. Cela indique que les gros arbres sont déjà matures indépendamment de leur âge. Ces résultats suggèrent que l'étape suivante est le développement de traitements sylvicoles visant à augmenter le taux de croissance radiale durant le stade initial de croissance, dans le but de produire le plus rapidement possible le plus de bois adulte.

\footnotetext{
*Corresponding author: hiro@agr.nagoya-u.ac.jp
} 
(a)

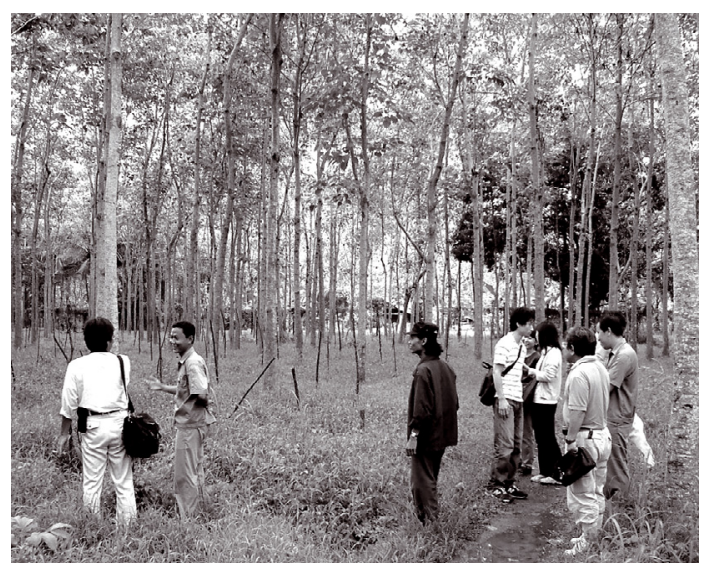

(b)

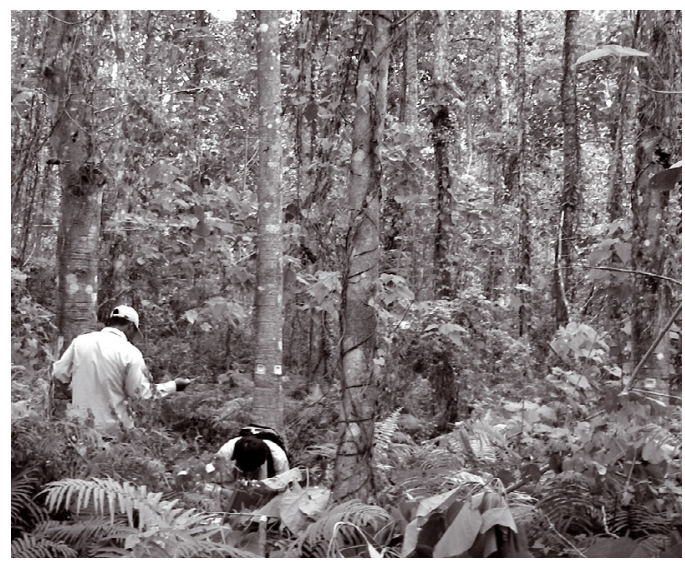

Figure 1. Sampling sites. (a) 3.5-year-old plantation in Palopo, Sulawesi, Indonesia. (b) 7-year-old plantation in Batu Putih, East Kalimantan, Indonesia.

\section{INTRODUCTION}

The development of human civilization has created various problems for the global environment (IPCC Special Report, 2006). Climate change induced by humans has resulted from increased atmospheric carbon dioxide $\left(\mathrm{CO}_{2}\right)$, while shortage of fossil fuels such as petroleum, and deforestation of tropical forests through illegal logging and inadequate forest management are major problems worldwide.

Demand for new biomass resources is increasing, so it is desirable to utilize recyclable woody biomass more effectively. However, because trees grow slowly, considerable time may elapse before new resources are available. Consequently, it is important to utilize fast-growing species.

The aim of our research program is to develop a solution to these problems from the viewpoint of woody biomass utilization; to plant fast-growing species to use as basic material. However, if plantations of such species are to be sustainable, their economic value must be increased by using the timber for building and furniture.

Many fast-growing tree species are available for plantation establishment, including Acacia spp., Paraserianthes spp., Populus spp. and Gmelina spp. (Zobel, 1981; Zobel and Buijtenen, 1989; Zobel and Sprague, 1998; Wahyudi et al., 1999; 2000). Among these examples, Gmelina arborea has received attention as a source of good quality pulp, medium density fiberboard (MDF) and plywood because of its beautiful white color and stronger fiber. G. arborea has potential as a material for higher-grade uses such as timber for buildings and for furniture. However, there is little data available on the timber qualities of $G$. arborea (Dvorak, 2004). It is therefore necessary to determine the wood quality of this species to enhance its value and expand its utilization. Based on this background, we focused on the wood qualities of G. arborea of different cambium ages, collected from age series plantations of the species in Indonesia.

This study had three objectives: (1) to determine the material parameters: longitudinal released strain of surface growth stresses, xylem density, and fiber length and microfibril angle in the middle layer of the secondary wall of wood fiber at the outermost surface of the secondary xylem; (2) to determine the effect of the lateral growth rate on the above material parameters; and (3) to identify the effect of the differences in cambium ages from trees of differing ages on the growth rate and qualities of $G$. arborea.

\section{MATERIALS AND METHODS}

\subsection{Plant material}

The samples for this study were G. arborea Roxb. of several selected cambium ages, collected from two islands in Indonesia (Fig. 1). The first group consisted of 50 trees from a 3.5-year-old plantation in Palopo ( $\left.3^{\circ} 0^{\prime} \mathrm{S} 120^{\circ} 16^{\prime} \mathrm{E}\right)$, Sulawesi Island. According to USDA soil taxonomy, the original soils in central Sulawesi were Ultisols. However, fertile soil was added to the original soil in this plantation before afforestation. The daily average temperature in Palopo is $26.5^{\circ} \mathrm{C}$ and annual rainfall is $2518.0 \mathrm{~mm}$. Planting distance is $5 \mathrm{~m}$ by $5 \mathrm{~m}$. The second group consisted of 36 trees from a 7-year-old plantation in Batu Putih ( $\left.1^{\circ} 24^{\prime} \mathrm{S} 118^{\circ} 21^{\prime} \mathrm{E}\right)$, near Berau, East Kalimantan. The East Kalimantan soils are classified as Inceptisols. Fertile soil was not added in this plantation prior to planting. The daily minimum temperature in Berau is $23.2^{\circ} \mathrm{C}$, the maximum is $31.8^{\circ} \mathrm{C}$, and annual rainfall is $2134 \mathrm{~mm}$. Initial spacing of the plantation was $3 \times 3 \mathrm{~m}$. The number of trees per hector is 1101 trees $\cdot \mathrm{ha}^{-1}$; 350 trees $\cdot \mathrm{ha}^{-1}$ after thinning twice.

All trees used in this study thus grew in a tropical rain-forest climate zone. Climate information was derived from meteorological data obtained from the world climate website (http://www. worldclimate.com/). All the trees tested were grown from seedlings. G. arborea trees are normally harvested for commercial use at 7 or 8 years old. Only a few trees past the harvesting age (i.e. more than 8 years old) are kept for seed orcharding. Consequently, in this study we tested only three sample trees in the 12-year-old plantation in Batu Putih. Although the number of samples is insufficient for statistical analysis, the results are helpful for understanding how the wood 
qualities develop in trees that have passed normal commercial harvesting age.

At each site the test trees were selected to represent a range of diameters at breast height $(D B H)$. Various material parameters were measured at the four cardinal points on each tree. The longitudinal released strain $(R S)$ of the surface growth stresses was first measured. A rectangular specimen was then collected at the point where the RS was measured, and used to measure xylem density $(X D)$, fiber length $(F L)$ and microfibril angle in the middle layer of the secondary wall $(M F A)$. The values measured at the four cardinal points were averaged for each tree. Results were compared with the $D B H$ of the tree, which gave a measurement of the lateral growth rate, since the sample trees came from plantings of known age. The lateral growth rate was calculated as half of the increment in $D B H$ per year.

\subsection{Longitudinal released strain of surface growth stresses $(R S)$}

For each standing tree, measurements were conducted at four cardinal points at breast height. A strain gauge (electric-wire strain gauge, $10 \mathrm{~mm}$ length, Kyowa) was glued to the exposed secondary xylem surface along the longitudinal direction and connected to a strain meter (UCAM-1A, Kyowa).

After measuring the initial strain on the stumpage, the surface stress was released using a handsaw, and the strain was recorded. The amount of the longitudinal released strain of growth stress was calculated by subtracting the initial measurement from the second reading (Okuyama et al., 1981; Yamamoto et al., 1989; Yoshida and Okuyama, 2002).

\subsection{Xylem density $(X D)$}

Samples $(1 \times 1 \times 1 \mathrm{~cm})$ were prepared from the rectangular specimens taken from the points where the $R S$ was measured. Samples were kept in desiccators with saturated saline for one week to become air-dried. The density was determined using the mercury displacement method (Kollmann and Cote, 1968).

\subsection{Fiber length $(F L)$}

After $X D$ had been determined, $F L$ and $M F A$ were measured. To measure $F L$ each specimen $(0.1(\mathrm{R}) \times 0.2(\mathrm{~T}) \times 1(\mathrm{~L}) \mathrm{cm})$ was treated with Schulze solution and $\mathrm{NaOH}(\mathrm{aq})$ and then fiberized (Cheng et al., 2000). The distribution of fiber length was measured automatically using a Fiber Quality Analyzer (Hi Res FQA, Op Test Equipment).

\subsection{Microfibril angle (MFA)}

A small specimen $(0.1(\mathrm{R}) \times 1(\mathrm{~T}) \times 1(\mathrm{~L}) \mathrm{cm})$ was used to determine $M F A$ by X-ray diffractometry (XD-D1w, Shimadzu) using the method of Cave (1966) and Meylan (1967).

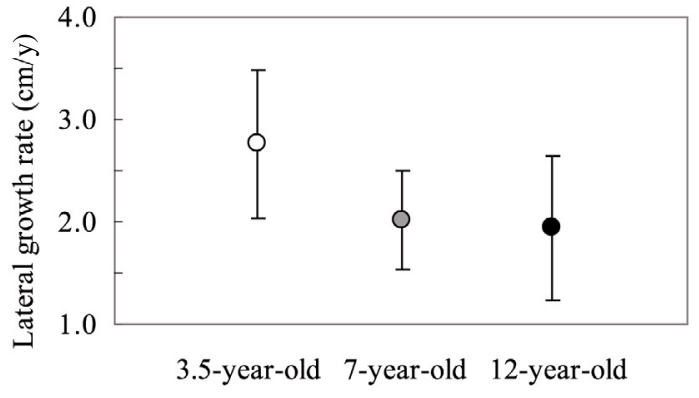

Figure 2. Lateral growth rate of tested Gmelina arborea. Each bar represents $\pm 1 \mathrm{SD}$.

\subsection{Statistical analysis}

Simple linear regression models ( $T$-test) were used to test the correlation between the lateral growth rate and xylem qualities; $R S, X D$, $F L$ and $M F A$. The differences in xylem qualities, $R S, X D, F L$ and $M F A$, between 3.5- and 7-year-old plantations were tested using a simple comparison method ( $T$-test).

\section{RESULTS}

\subsection{Lateral growth rate}

Figure 2 presents the lateral growth rate of sampled trees at the three plantations. The average lateral growth rate was $2.76 \pm 0.72\left(\mathrm{~cm} \cdot \mathrm{y}^{-1}\right)$ in the 3.5-year-old plantation in Palopo, $2.02 \pm 0.48\left(\mathrm{~cm} \cdot \mathrm{y}^{-1}\right)$ in the 7-year-old plantation in Batu Putih, and $1.94 \pm 0.71\left(\mathrm{~cm} \cdot \mathrm{y}^{-1}\right)$ in the 12-year-old plantation in Batu Putih. The 3.5-year-old plantation (Palopo), which had not reached harvest age, had a faster rate than the 7- and 12-yearold plantations (Batu Putih), which were harvestable.

\subsection{Longitudinal released strain of surface growth stresses}

The effect of the lateral growth rate on $R S$ is shown in Figure 3. The average value of $R S$ at each plantation is listed in Table I.

The $R S$ was constant regardless of the lateral growth rate. This indicates that the lateral growth rate did not significantly affect $R S$ at any plantation.

The differences in $R S$ between the 3.5- and 7-year-old plantations were analyzed using a simple comparison method. The results showed there was no difference between them. Subjectively, the differences between the 3.5-, 7- and 12-year-old plantations are not clear. Consequently, $R S$ is not correlated with the cambium age.

\subsection{Xylem density}

The effect of the lateral growth rate on $X D$ is shown in Figure 4. The averaged value of $X D$ at each plantation tested is listed in Table I. 


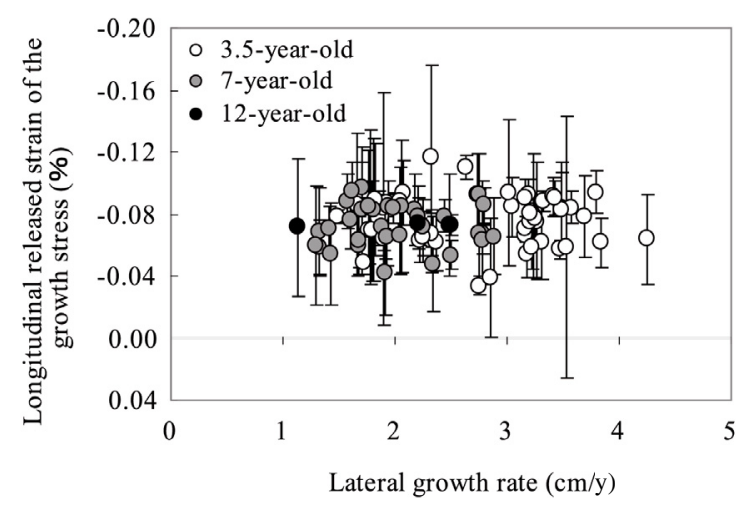

Figure 3. Effect of the lateral growth rate on the longitudinal released strain of the surface growth stress. Each bar represents \pm 1 SD.

Table I. Average $R S, X D, M F A$ and $F L$ in each tested location.

\begin{tabular}{lccc}
\hline Averaged value & 3.5-year-old & 7-year-old & 12-year-old \\
\hline$R S(\%)$ & -0.0753 & -0.0735 & -0.0726 \\
$X D\left(\mathrm{~g} / \mathrm{cm}^{3}\right)$ & $( \pm 0.0163)^{\#}$ & $( \pm 0.0138)$ & $( \pm 0.0012)$ \\
& 0.56 & 0.58 & 0.52 \\
$M F A(\mathrm{deg})$. & $( \pm 0.04)$ & $( \pm 0.04)$ & $( \pm 0.04)$ \\
& 17.3 & 17.3 & 15.2 \\
$F L(\mathrm{~mm})$ & $( \pm 2.4)$ & $( \pm 2.4)$ & $( \pm 2.5)$ \\
& 1.20 & 1.35 & 1.29 \\
Number of trees & $( \pm 0.12)$ & $( \pm 0.10)$ & $( \pm 0.12)$ \\
\hline
\end{tabular}

$R S$ : Longitudinal released strain of surface growth stress. $X D$ : Air-dried density at the surface of the xylem. MFA: Microfibril angle in the middle layer of the secondary wall at the surface of the xylem. $F L$ : Fiber length at the surface of the xylem. \#: \pm 1 SD.

The lateral growth rate did not significantly affect $X D$ at any plantation. The differences in $X D$ between the 3.5- and 7-year-old plantations were analyzed using a simple comparison method; the results indicated that there was no difference between them. Subjective comparison of both with the 12-year-old plantation also suggested there was no difference in $X D$ with age.

\subsection{Fiber length}

The effect of the lateral growth rate on $F L$ is shown in Figure 5. The average value of $F L$ at each plantation is listed in Table I.

At the 7-year-old plantation, the lateral growth rate did not significantly affect $F L$. At this plantation, $F L$ was uniform regardless of the lateral growth rate. However, in the 3.5 -year-old plantation, a positive correlation at the $5 \%$ level ( $p=0.035<0.050)$ was observed between $F L$ and the lateral growth rate.

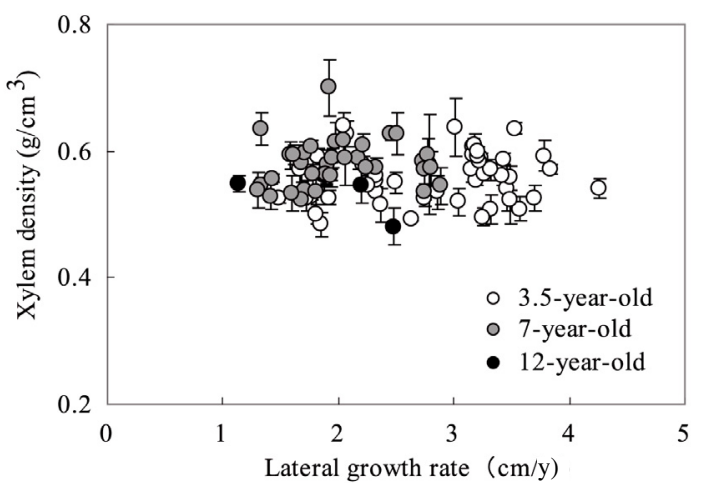

Figure 4. Effect of the lateral growth rate on xylem density. Each bar represents $\pm 1 \mathrm{SD}$.

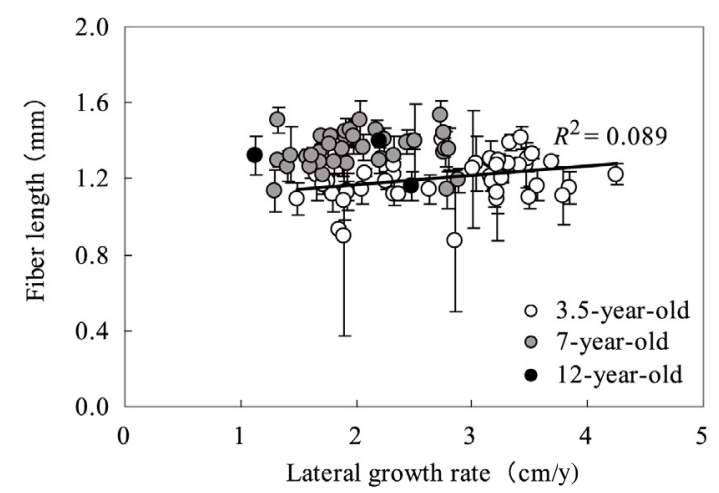

Figure 5. Effect of the lateral growth rate on fiber length. $R^{2}$ represents the contribution ratio at the 3.5-year-old plantation. Each bar represents $\pm 1 \mathrm{SD}$.

The differences in $F L$ between these two plantations (3.5year-old and 7-year-old) were also analyzed using a simple comparison method. The results showed that there was a significant correlation at the $1 \%$ level $(p \ll 0.010)$. The averaged $F L$ increases from 3.5 to 7 years, but decreases in the 12 -yearold plantation.

\subsection{Microfibril angle}

The effect of the lateral growth rate on MFA is shown in Figure 6. The average value of $M F A$ at each tested plantation is listed in Table I. The lateral growth rate does not significantly affect the MFA at any plantation. The differences in MFA between the 3.5- and 7-year-old plantations were also analyzed by a simple comparison method. This analysis again indicated that there was no significant difference between them. There are some differences between the 3.5-, 7- and 12-yearold plantations, but these are not statistically significant. The averaged value of MFA is smallest in the 12-year-old plantation. 


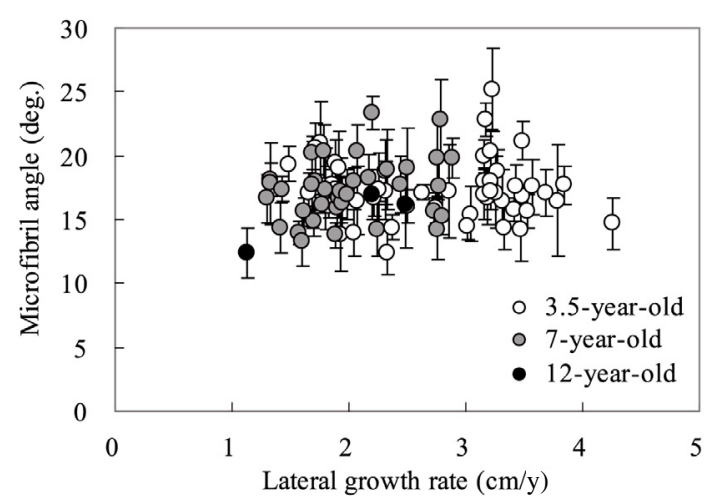

Figure 6. Effect of the lateral growth rate on the microfibril angle. Each bar represents \pm 1 SD.

\section{DISCUSSION}

\subsection{Lateral growth rate}

The lateral growth rate in the 3.5-year old plantation examined was twice that reported for a lightly-thinned Gmelina plantation in Nigeria (Onyekwelu et al., 2006), and about the same as or slightly higher than that in a well-controlled plantation in Costa Rica (Piotto et al., 2003). Lateral growth is affected by the level of thinning (Morataya et al., 1999), and decreases as the plantation density increases (Zhu et al., 2007). In the present study, thinning conditions were identical in all three plantations investigated. The results showed that the lateral growth rate was greater at the initial growth stage, and decreased gradually as the cambium age increased. Comparison between the 7- and 12-year-old plantations suggests that the lateral growth rate is already stable at seven years. The lateral growth rate is thus faster until harvesting age is attained.

\subsection{Longitudinal released strain of growth stresses}

Heart splitting at the cross-section of the log and crooking of the sawn board are often induced by growth stress, which seriously decreases the yield ratio of forest products (Archer, 1986; Kubler, 1987; Okuyama and Sasaki, 1979). Okuyama et al. (2004) reported that $R S$ does not depend on the lateral growth rate, but the larger the lateral growth rate and the higher the $R S$, the more severe the heart splitting. Considering the present results in the light of the conclusions of Okuyama et al. (2004), we consider that processing defects, especially heart splitting, do not depend on the cambium age. If so, it is a matter of concern that heart splitting in $G$. arborea becomes severe at a certain diameter, regardless of cambium age.

In the present study, the average $R S$ value for each tested plantation was a little more than $-0.07 \%$, excluding an abnormally large value of $-0.16 \%$ at one measurement point. The average value of $-0.07 \%$ observed here is small compared with typical $R S$ values in tension wood in general, which are often -0.15 to $-0.30 \%$ (Okuyama et al., 1994). This suggests that there is almost no need to be apprehensive of defects due to tension wood growth stress in plantations of Gmelina arborea.

\subsection{Xylem density}

Xylem density in G. arborea is uniform regardless of the lateral growth, and is not correlated with the cambium age. It seems that $X D$ had already reached the value for harvesting in the 3.5-year-old plantation. The correlation between growth ring width and density depends on the differences in the anatomical basis for extensive variation in general (Saranpää, 2003). Zobel and Jett (1995) noted that the diffuse-porous hardwoods (e.g. Populus tremuloides, Eucalyptus grandis) usually show little or no relationship between growth rate and xylem density. G. arborea is also a diffuse-porous hardwood species, and thus shows the same results as those examples.

\subsection{Fiber length}

For the 3.5-year-old plantation, we consider that small diameter trees with shorter $F L$ were still producing juvenile wood, whereas those with a large diameter had already started to form mature wood that had almost the same $F L$ as wood from the 7-year-old plantation. Therefore, there is a positive correlation between $F L$ and the lateral growth rate in the 3.5year-old plantation. Maturation therefore seems to be more dependent on diameter, that is, division of the cambial cells, than on the real age of the cambium. This means that a faster growth rate promotes the earlier formation of mature wood. Consequently, developing silvicultural treatments to increase the lateral growth rate (e.g. optimizing planting distance and thinning intensity) would increase the percentage of high-quality mature wood.

\subsection{Microfibril angle}

Microfibril angle is not correlated with the cambium age, suggesting that MFA had already reached a matured value in the 3.5-year-old plantation.

The MFA is considered to have a major role in controlling certain fiber qualities, including fiber stiffness and dimensional stability (Barnett and Bonham, 2004).

MFA values smaller than 10 degrees are often correlated with high tensile stress generation in tension wood compared with normal wood (Baba et al., 1996; Okuyama et al., 1990; 1994; Yamamoto et al., 1992). In the present study, the MFA values were greater than 10 degrees in all plantations. Consequently, there is no need to be concerned with negative effects due to tension wood in plantations of G. arborea.

\section{CONCLUSIONS}

From the observations above, we draw the following conclusions:

The xylem qualities, $R S, X D, F L$ and $M F A$, had already reached values appropriate for harvesting, except for smaller diameter trees in the 3.5-year-old plantation. The larger diameter trees in that plantation had already matured regardless of their cambium age. 
These conclusions suggest that the next step is to develop silvicultural treatments to increase the lateral growth rate during the early growing stage. This would increase the percentage of high-quality mature wood in the forest product.

Acknowledgements: This work was supported by Global Environment Research Fund (Prof. Yuji Ide group); the Ministry of the Environment, Government of Japan. We greatly appreciate the assistance of Mr. Noriaki Kamiya, Mashiki Japan Corp., in arranging access to the plantations. Our thanks also to PT. Sumalindo Lestari Jaya Tbk. and PT. Panca Usaha Palopo Plywood for their contribution to the sample preparation, and to Dr. Barry Roser, Shimane Univ., Japan, for valuable comments on the manuscript.

\section{REFERENCES}

Archer R.R., 1986. Growth stresses and strains in trees, Springer-Verlag, New York, $244 \mathrm{p}$.

Baba K., Ona T., Takabe K., Itoh T., and Ito K., 1996. Chemical and anatomical characterization of the tension wood of Eucalyptus camaldulensis L. Mokuzai Gakkaishi 42: 795-798.

Barnett J.R. and Bonham V.A., 2004. Cellulose microfibril angle in the cell wall of wood fibres. Biol. Rev. 79: 461-472.

Cave I.D., 1966. Theory of X-ray measurement of microfibril angle. For. Prod. J. 16: 37-42.

Cheng Z., Fujiwara S., Ohtani Y., and Sameshima K., 2000. A new method of sample preparation for kenaf bast fiber length analysis with automated fiber length analyzer. Holzforschung 54: 213-218.

Dvorak W.S., 2004. World view of Gmelina arborea: opportunities and challenges. New For. 28: 111-126.

IPCC Special Report, 2006. Carbon Dioxide Capture and Storage Summary for Policymakers, Web version, Intergovernmental Panel on Climate Change.

Kollmann F.P. and Cote Jr W.A., 1968. Principles of wood science and technology solid wood, Springer-Verlag, Berlin-Heidelberg-New York, $247 \mathrm{p}$.

Kubler H., 1987. Growth stresses in trees and related wood properties. For. Prod. Abs. 10: 61-119.

Meylan B.A., 1967. Measurement of microfibril angle by X-ray diffraction. For. Prod. J. 17: 51-58.

Morataya R., Galloway G., Berninger F., and Kanninen M., 1999. Foliage biomass - sapwood (area and volume) relationships of Tectona gtandis L.F. and Gmelina arborea Roxb.: silvicultural implications. For. Ecol. Manage. 113: 231-239.

Okuyama T. and Sasaki Y., 1979. Crooking during lumbering due to residual stresses in the tree. Mokuzai Gakkaishi 25: 681-687.

Okuyama T., Sasaki Y., Kikata Y., and Kawai N., 1981. Seasonal change in growth stress in tree trunks. Mokuzai Gakkaishi 27: 681-687.
Okuyama T., Yamamoto H., Iguchi M., and Yoshida M., 1990. Generation process of growth stresses in cell walls II. Growth stresses in tension wood. Mokuzai Gakkaishi 36: 797-803.

Okuyama T., Yamamoto H., Yoshida M., Hattori Y., and Archer R.R., 1994. Growth stresses in tension wood: role of microfibrils and lignification. Ann. Sci. For. 51: 291-300.

Okuyama T., Doldan J., Yamamoto H., and Ona T., 2004. Heart splitting at crosscutting of eucalypt logs. J. Wood Sci. 50: 1-6.

Onyekwelu J.C., Mosandl R., and Stimm B., 2006. Productivity, site evaluation and state of nutrition of Gmelina arborea plantations in Oluwa and Omo forest reserves, Nigeria. For. Ecol. Manage. 229: 214-227.

Piotto D., Montagnini F., Ugalde L., and Kanninen M., 2003. Performance of forest plantations in small and medium-sized farms in Atlantic lowlands of Costa Rica. For. Ecol. Manage. 175: 195-204.

Saranpää P., 2003. Wood density and growth. In: Barnett J.R. and Jeronimidis G. (Eds.), Wood Quality and its biological basis, Blackwell publishing Ltd, CRC Press, pp. 87-117.

Yamamoto H., Okuyama T., and Iguchi M., 1989. Measurement of surface growth stress in a leaning stem. Mokuzai Gakkaishi 35: 595601.

Yamamoto H., Okuyama T., Sugiyama K., and Yoshida M., 1992. Generation process of growth stresses in cell walls ?. Action of the cellulose microfibril upon the generation of the tensile stresses. Mokuzai Gakkaishi 38: 107-113.

Yoshida M. and Okuyama T., 2002. Technique for measuring growth stress on the xylem surface using strain and dial gauges. Holzforschung 56: 461-467.

Wahyudi I., Okuyama T., Hadi Y.S., Yamamoto H., Yoshida M., and Watanabe H., 1999. Growth stress and strain of Acacia mangium. For. Prod. J. 49: 77-81.

Wahyudi I., Okuyama T., Hadi Y.S., Yamamoto H., Yoshida M., and Watanabe H., 2000. Relationships between growth rate and growth stresses in Paratherianthes falcataria grown in Indonesia. J. Trop. For. Prod. 6: 95-105.

Zhu J.Y., Scott C.T., Scallon K.L., and Myers G.C., 2007. Effect of plantation density on wood density and anatomical properties of red pine. Wood Fiber Sci. 39: 502-512.

Zobel B.J., 1981. Wood quality from fast-grown plantation. Tappi J. 64: 71-74.

Zobel B.J. and van Buijtenen J.P., 1989. Wood variation. Its causes and control, Springer-Verlag, Berlin, Germany, 363 p.

Zobel B.J. and Jett J.B., 1995. Genetics of Wood Production, SpringerVerlag, Berlin, Germany, 337 p.

Zobel B.J. and Sprague J.R., 1998. Juvenile wood in forest trees, Springer-Verlag, Berlin, Germany, 300 p. 